\section{Category}

Organo- and

Biocatalysis

\section{Key words}

supramolecular catalysis

iminium catalysis

vinylogous Michael addition

anion binding

Y. GU, Y. WANG, T.-Y. YU, Y.-M. LIANG, P.-F. XU* (LANZHOU UNIVERSITY,

P. R. OF CHINA)

Rationally Designed Multifunctional Supramolecular Iminium Catalysis: Direct Vinylogous Michael Addition of Unmodified Linear Dienol Substrates

Angew. Chem. Int. Ed. 2014, 53, 14128-14131.

\title{
Amine-Catalyzed Direct Vinylogous Michael Addition of Dienols to Enals
}

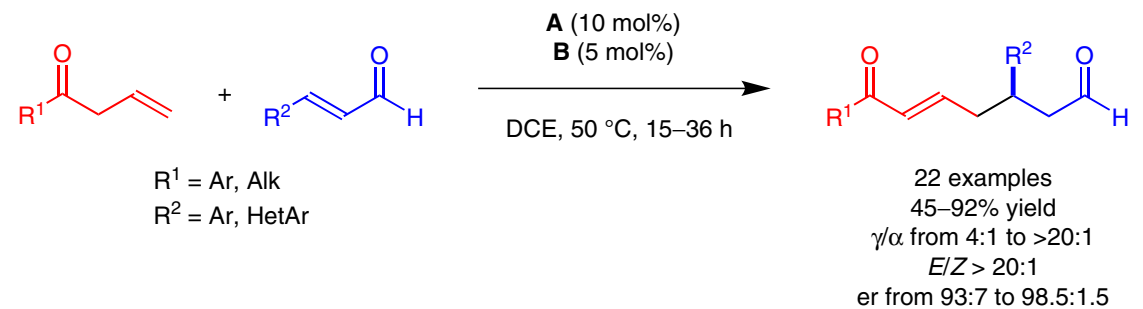

Selected examples:<smiles>O=CCC(CC=CC(=O)c1ccccc1)c1ccccc1</smiles>

$88 \%$ yield $\gamma / \alpha>20: 1$ er $=97.5: 2.5$<smiles>O=CCC(CC=CC(=O)c1ccccc1)c1ccc([N+](=O)[O-])cc1</smiles>
$92 \%$ yield $\gamma / \alpha>20: 1$ er $=97: 3$<smiles>O=CC(=O)CC(CC=CC(=O)O)c1ccccc1</smiles>

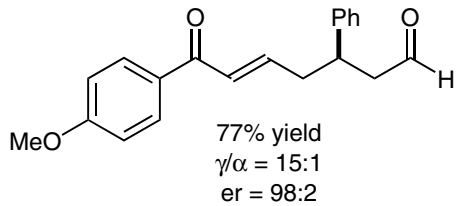<smiles>COC(c1ccccc1)(c1ccccc1)C1CCCN1</smiles>
A<smiles>O=CCC(C/C=C/C(=O)c1ccccc1)c1ccco1</smiles>

$80 \%$ yield $\gamma / \alpha=5: 1$ er $=93: 7$

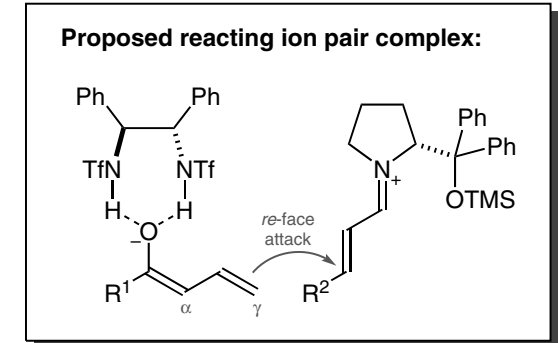

Significance: Xu and co-workers report a vinylogous Michael addition of acyclic alkyl and aryl allyl ketones to enals. The reaction is catalyzed by a chiral secondary amine (A) and a chiral hydrogen bond donor (B), which in combination enable the formation of the desired enones in moderate to excellent yields and regioselectivities, and with excellent enantioselectivities. The scalability of the reaction was proven in one experiment starting with 1.46 gram of phenyl allyl ketone.

SYNFACTS Contributors: Benjamin List, Lucas Schreyer Synfacts 2015, 11(1), 0092 Published online: 15.12.2014 DOI: 10.1055/s-0034-1379627; Reg-No.: B13114SF
Comment: While the application of catalyst $\mathbf{A}$ in combination with a 'regular' Brønsted acid or base (e.g., benzoic acid or DABCO) already furnished small amounts of desired product with excellent enantioselectivity, it required a second, anion-binding catalyst (B) to enhance the reactivity of the proposed $\alpha, \beta$-unsaturated iminium ion intermediate by ion pair separation and to shield the $\alpha$-position of the nucleophile, effecting the desired $\gamma$-selectivity. The concept of supramolecular iminium ion catalysis was previously reported by the same group (Angew. Chem. Int. Ed. 2012, 51, 12339). 